\title{
Histoire des AOS
}

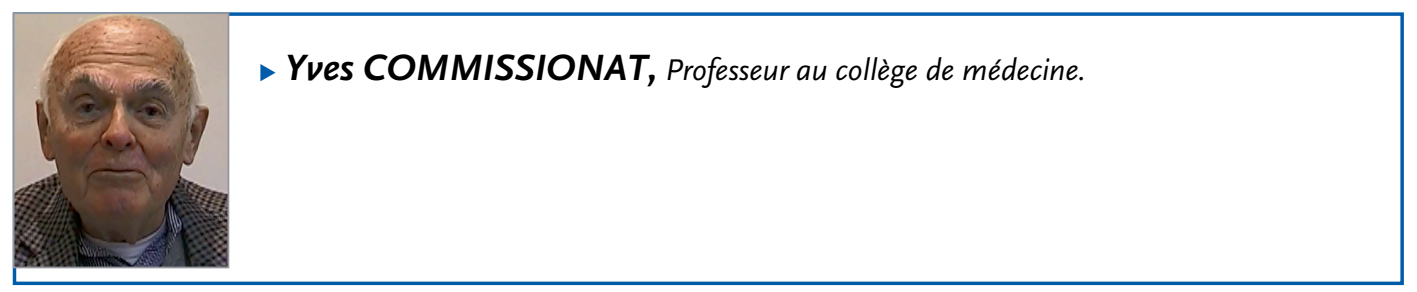

AOS $n^{\circ} 279-2016$

Les Actualités Odonto-Stomatologiques sont l'une des plus anciennes revues françaises traitant de la bouche et des dents. Le Professeur
Yves Commissionat, membre du Comité de Rédaction depuis des décennies, nous en raconte l'histoire. 